\title{
Substituted hydroxyapatite: a recent development
}

\author{
Yu Jiang, Zhiyu Yuan and Jie Huang \\ Department of Mechanical Engineering, \\ University College London, London WC1E 7JE UK
}

\begin{abstract}
Hydroxyapatite $\left(\mathrm{HA}, \mathrm{Ca}_{10}\left(\mathrm{PO}_{4}\right)_{6}(\mathrm{OH})_{2}\right)$ constitutes the major inorganic hard tissues, such as bone and teeth. Various substitutions in the apatite structure have been developed for a wide range of biomedical applications, such as the bone repair and tissue regenerations; bioactive and/or antibacterial coating for medical devices, biomarkers or carriers in drug/gene delivery systems, and the biomagnetic agents for cancer treatment. In this review, the recent development on substituted HA was overviewed from the aspects of enhanced osteoconductivity and multifunctionality of mono- and multi- cationic and anionic substitutions.
\end{abstract}

Keyword: hydroxyapatites; co-substitution; osteoconductivity; antibacterial; multifunctionality; drug delivery.

\section{Introduction}

Bioceramic is a group of ceramics used in the repair and reconstruction of diseased or damaged body parts, mostly related to the skeletal system, comprising bone, joints and teeth. The most extensively used synthetic calcium phosphate ceramic is hydroxyapatite (HA) because of its chemical similarities to the inorganic component of bone and teeth (Table 1). HA with a chemical formula of $\mathrm{Ca}_{10}\left(\mathrm{PO}_{4}\right)_{6}(\mathrm{OH})_{2}$, has a theoretical composition of $39.6 \mathrm{wt} \% \mathrm{Ca}, 18.5 \mathrm{wt} \%$ $\mathrm{P}$; and $\mathrm{Ca} / \mathrm{P}$ molar ratio of 1.667. HA possesses a hexagonal lattice and a $\mathrm{P} 63 / \mathrm{m}$ space group, with cell dimension of $\mathrm{a}=\mathrm{b}=0.9418 \mathrm{~nm}$ and $\mathrm{c}=0.6884 \mathrm{~nm}$ [1].

The mineral phase of bone, biological apatite, is not stoichiometric hydroxyapatite. The apatite is hospitable to a variety of cationic and anionic substitutions. The type and amount of these 
ionic substitutions can be varied from a high level of $\mathrm{CO}_{3}{ }^{2-}(3-8 \mathrm{wt} \%)$ to low concentrations of $\mathrm{Mg}^{2+}$ and $\mathrm{Na}^{+}$and $\mathrm{F}^{-}$, etc, as shown Table 1. Substitution of $(\mathrm{Ca}),\left(\mathrm{PO}_{4}\right)$ or $(\mathrm{OH})$ groups in the apatite structure changes the lattice parameters, morphology, solubility without significantly altering the hexagonal symmetry. It either originates from mineral ions naturally present in human body, such as $\mathrm{CO}_{3}{ }^{2-}$ and $\mathrm{F}^{-}$for increasing degradation rates and bioactivity, reducing solubility; or from specially formulated ions such as strontium $\left(\mathrm{Sr}^{2+}\right)$, zinc $\left(\mathrm{Zn}^{2+}\right)$ and silver $\left(\mathrm{Ag}^{+}\right)$to deliver particular functions.

\begin{tabular}{|l|l|l|l|l|}
\hline Composition (wt\%) & HA & Bone & Dentin & Enamel \\
\hline Calcium $(\mathrm{Ca})$ & 39.6 & 34.8 & 35.1 & 36.5 \\
\hline Phosphorus $(\mathrm{P})$ & 18.5 & 15.2 & 16.9 & 17.7 \\
\hline Carbonate $\left(\mathrm{CO}_{3}\right)$ & 0 & 7.4 & 5.6 & 3.5 \\
\hline Magnesium $(\mathrm{Mg})$ & 0 & 0.72 & 1.23 & 0.44 \\
\hline Chloride $(\mathrm{Cl})$ & 0 & 0.13 & 0.01 & 0.30 \\
\hline Sodium $(\mathrm{Na})$ & 0 & 0.9 & 0.6 & 0.5 \\
\hline Potassium $(\mathrm{P})$ & 0 & 0.03 & 0.05 & 0.08 \\
\hline Fluoride $(\mathrm{F})$ & 0 & 0.03 & 0.06 & 0.01 \\
\hline
\end{tabular}

Table 1. Chemical compositions of HA, bone, dentin and enamel [2].

One of the drives in developing substituted HA has been focused on promoting osteogenesis by enhancing their osteoconductivity. The recent development has moved from improved bioactivity towards the incorporation of therapeutic ions for antibacterial properties, inhibition of osteoclast activity, applications as delivery carriers, or biocompatible imaging contrast agents (Fig 1). In this review, a recent development of substituted HA is discussed from the aspect of bioactivity with enhanced osteogenesis, inhibition or treatment of osteoporosis, prevention of infection with antibacterial properties towards cancer treatment, drug and gene delivery.

\section{Preparation of HA}

There are numerous methods for the preparation of synthetic apatites, including aqueous reactions, solid-state reactions and hydrothermal reactions. The aqueous reactions may be divided into chemical precipitation and hydrolysis methods. Chemical precipitation is the commonly used method due to its simplicity and the ability of producing a wide variety of particle sizes and morphologies. They consist of dropwise addition of phosphate solution into a stirring solution of calcium solution. Addition of ammonium hydroxide is needed to keep the $\mathrm{pH}$ of the reaction alkaline to ensure the formation of HA after sintering. 
The concentrations of reagents must be maintained at $1.667 \mathrm{Ca} / \mathrm{P}$ molar ratio for stoichiometric HA. The concentration of calcium can be adjusted if substitution for calcium (e.g. strontium, magnesium etc) is required. Similarly, the phosphate concentration can be adjusted and replaced with required amount of carbonate or silicate when they are desired. Fluoride or chloride substituted apatite can be prepared by addition of fluoride or chloride ions in the reactions.

\section{Hydroxyapatite}

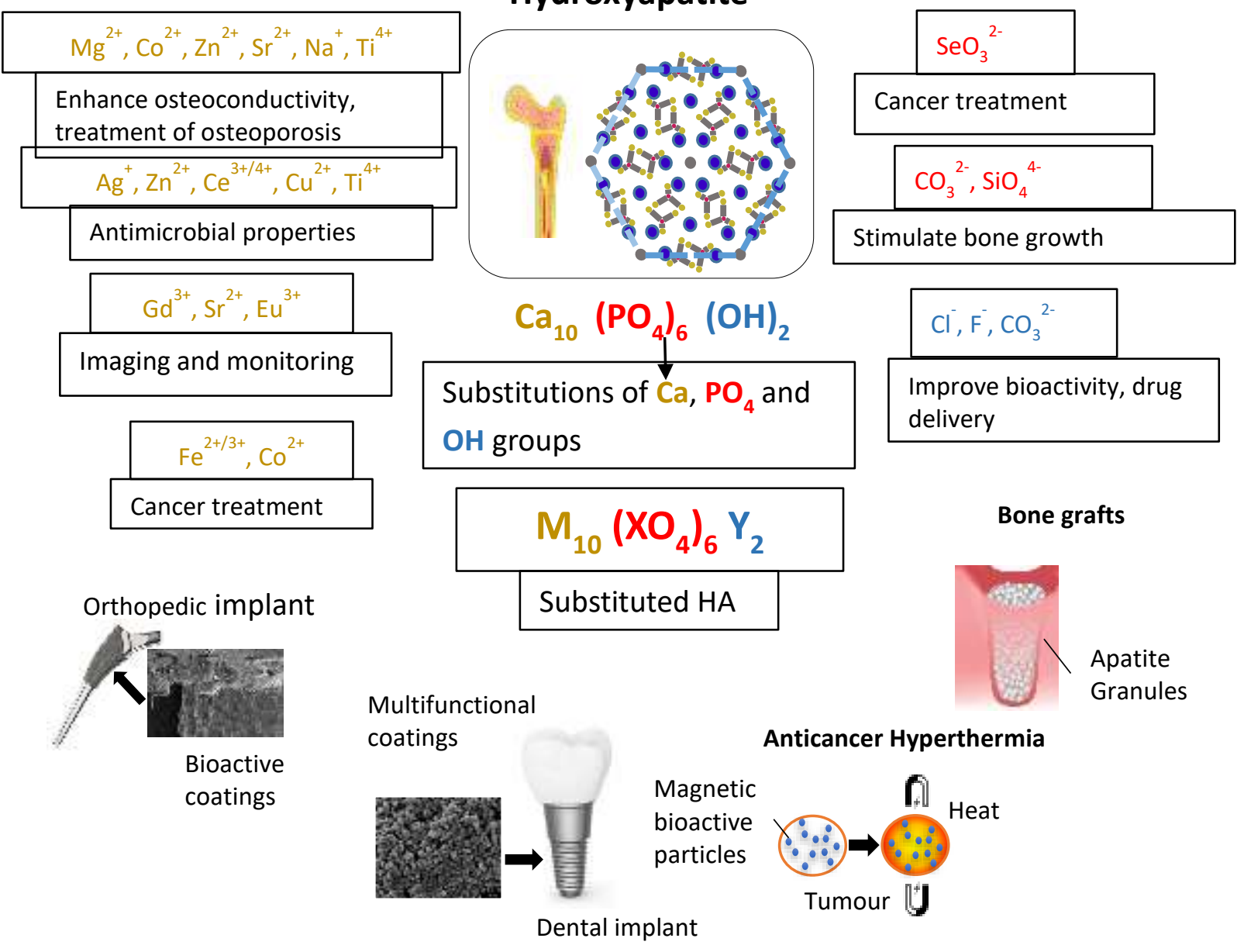

Figure 1 Mono- and multi- cationic and anionic substituted hydroxyapatite with enhanced osteoconductivity and multifunctionality for biomedical applications

\section{Substituted HA with enhanced bioactivity}

A general formula of substituted apatite is $\mathrm{M}_{10}\left(\mathrm{XO}_{4}\right)_{6} \mathrm{Y}_{2}$. There are 3 groups for substitution: (a) $\mathrm{M}$ represents cations such as $\mathrm{Ca}^{2+}, \mathrm{Na}^{+}, \mathrm{Mg}^{2+}, \mathrm{Zn}^{2+}, \mathrm{Sr}^{2+}, \mathrm{Cu}^{2+}, \mathrm{Fe}^{2 / 3+}$; (b) $\mathrm{XO}_{4}$ usually are $\mathrm{PO}_{4}{ }^{3-}, \mathrm{CO}_{3}{ }^{2-}, \mathrm{SiO}_{4}{ }^{4-}, \mathrm{SeO}_{3}{ }^{2-}$ and (c) $\mathrm{Y}$ represents an anion groups of $\mathrm{OH}^{-}, \mathrm{CO}_{3}{ }^{2-}, \mathrm{F}^{-}, \mathrm{Cl}^{-}$. 
Although the amount of ions that can be incorporated into HA structure is limited, specifically designed biological functions can be achieved by tailoring the types and amount of 'functional' doping or substitutions in HA structure [3]. In addition to mono-ionic substitutions, recent studies have been towards multiple substitutions to develop multi-ionic co-substituted HA. In comparison with mono-ionic substituted HA, the combinations provide new multifunctional materials with add-on biological functions to further their applications.

\subsection{Substitution of calcium group}

Many studies found that not only $\mathrm{Ca}^{2+}$ isovalent ions, such as $\mathrm{Mg}^{2+}, \mathrm{Zn}^{2+}, \mathrm{Sr}^{2}$, mono- or multivalent ions such as $\mathrm{Na}^{+}, \mathrm{Ce}^{3 / 4+}, \mathrm{Ga}^{3+}, \mathrm{Eu}^{3+}$, and $\mathrm{Ti}^{4+}$ have also been substituted into $\mathrm{HA}$ to enhance bioactivity.

\section{Magnesium substituted HA (MgHA)}

Magnesium ( $\mathrm{Mg}$ ) is an essential trace element in human bone and teeth (Table 1) [4]. $\mathrm{Mg}$ is involved in all stages of skeletal metabolism and is important for bone growth. Mg deficiency is known related to osteopenia and bone fragility [5]. $\mathrm{Mg}$ is known to promote several proteins, including collagen, vascular endothelial growth factor (VEGF), and hypoxia-inducible factor (HIF-2a) that responsible for the bone regeneration [4]. Substituting $\mathrm{Ca}$ by $\mathrm{Mg}$ in $\mathrm{HA},\left(\mathrm{Ca}_{10-}\right.$ $\left.{ }_{x} \mathrm{Mg}_{\mathrm{x}}\left(\mathrm{PO}_{4}\right)_{6}(\mathrm{OH})_{2}, \mathrm{MgHA}\right)$, enhanced osteoconductivity was achieved when compared to stoichiometric HA [4]. MgHA was able to promote the differentiation and proliferation of osteoblast cells, and mineralization of extracellular matrix (ECM) [6]. Having the optimum amount of $\mathrm{Mg}^{2+}$ is also critical for preventing and reversing osteoporosis. It has been demonstrated that low level $\mathrm{Mg}^{2+}(<15 \mathrm{mM})$ could enhance the proliferation osteoclast cells and their function, while high level $\mathrm{Mg}^{2+}(>15 \mathrm{mM})$ reduced osteoclast cell metabolism, although protein contents and cell differentiation were less affected [7]. MgHA has shown an increased solubility and biodegradability, which contribute to the partial dissolution of the HA crystals. Partial dissolution of HA coating further increased the $\mathrm{Ca}^{2+}$ and $\mathrm{PO}_{4}{ }^{3-}$ concentrations around the coating materials and triggered cell differentiation and bone formation $[8,9]$.

\section{Cobalt substituted HA (CoHA)}

Cobalt (Co) naturally exists in human body and has various biological functions, such as promoting vascularization in bone tissue [10]. By incorporating Co into HA, the osteogenetic potential of CoHA was observed. The new bone formation is proportional to the concentrations of $\mathrm{Co}^{2+}$ in $\mathrm{CoHA} . \mathrm{Co}^{2+}$ is known to have toxic effects to osteoblasts by inhibiting cell 
proliferation and the expression of osteogenic genes in vitro [10]. The cytotoxicity and genotoxicity of $\mathrm{Co}^{2+}$ were due to the hypoxia (low oxygen pressure), which could have positive effects for bone remodelling [11].

Bose et al. [12] found that the artificially induced hypoxia by $\mathrm{Co}^{2+}$ ions could promote the expression of erythropoietin (EPO) genes and enhance the production of vascular endothelial growth factor (VEGF), which then contribute to neovascularization [12]. An in vivo testing at a rat alveolar defect showed good vascularization and osteogenesis abilities of CoHA (Table 2). The osteoporosis-induced bone defects were filled with dense network of collagen fibers and the mineral deposition rate of CoHA bone graft was higher than that of pure HA [13].

\section{Zinc substituted HA (ZnHA)}

Zinc ( $\mathrm{Zn})$ is present in biological tissues, mostly in bones, and involved in many biological activities, such as nucleic acid metabolism, enzyme and protein synthesis as well as hormonal activity [14]. The substitution of $\mathrm{Zn}$ into HA, the degree of crystallinity of $\mathrm{ZnHA}$ decreased, as well as both a- and c-axes of the unit cell parameters $[15,16]$.

$\mathrm{ZnHA}$ is known for the inhibition of bone resorption. It promotes the growth and development of skeletal system by stimulating the osteoblast activity and inhibiting the osteoclast differentiation (Table 2) [17]. However, the mechanism of $\mathrm{Zn}$ affects the biological responses still remains to be fully understood [18].

\section{Strontium substituted HA (SrHA)}

Similarly to calcium, strontium ( $\mathrm{Sr}$ ) is naturally accumulated in skeletal system, and is an important element for bone metabolism [19]. Utilising the therapeutic property of $\mathrm{Sr}^{2+}, \mathrm{Sr}$ substituted HA (SrHA) has been developed for the treatment of osteoporosis. Not only it was able to stimulate the proliferation, osteogenic differentiation, angiogenic factor expression of human osteoblast-like cells (MG-63), but also to inhibit bone resorption by limiting the osteoclast activity (Table 2) [19]. In vivo study from a calvarial rat model showed that both bone mineral density and mechanical properties of SrHA increased with $\mathrm{Sr}^{2+}$ addition (Table 2), which indicate the potential usage of SrHA as a promising scaffold in bone regeneration [19]. In addition, therapeutic $\mathrm{Sr}^{2+}$ can be delivered from a porous SrHA scaffold, which has shown a good drug-loading capacity and sustained drug release properties. This suggested SrHA is suitable for drug-delivery applications [19].

\section{Sodium substituted HA (NaHA)}


Sodium (Na) is another essential trace element in human bone (Table 1). By substitution of $\mathrm{Na}$ into HA, an enhanced release rate of calcium and hydroxyl ions was observed from NaHA. The charge and size differences between $\mathrm{Na}$ and $\mathrm{Ca}$ have led to an instability of NaHA structure, which positively influenced its osteoconductivity [20]. This improved osteoconductivity offers a potential to be used as bone grafts.

\section{Titanium substituted HA (TiHA)}

Titanium (Ti) and titanium alloys have been successfully applied as medical implants. Recently, Ti substituted HA (TiHA) has been attracting increasing attention due to good biocompatibility and low side effects (i.e. cytotoxicity) [42]. TiHA was able to enhance the formation of bone-like apatite [43], and stimulate the attachment and proliferation of human osteoblast (HOB) cells due to the favourable nanotopography of TiHA (Table 2). TiHA has been considered as an alternative coating material to HA in dental and orthopedic fields [44].

\section{Multi-ionic co-substituted HA}

In addition to mono-substitution, $\mathrm{Zn}$ and $\mathrm{Mg}$ co-substituted $\mathrm{HA}, \mathrm{Zn} / \mathrm{MgHA}$ [Ca10-x${ }_{\mathrm{y}} \mathrm{Zn}_{\mathrm{x}} \mathrm{Mg}_{\mathrm{y}}\left(\mathrm{PO}_{4}\right)_{6}(\mathrm{OH})_{2}$ ], has been synthesized by sol-gel method to promote bone formation [46]. $\mathrm{Zn}^{2+}$ ions are more favourable to be substituted into Ca site than $\mathrm{Mg}$ in HA. With increasing of $\mathrm{Zn}^{2+}$ and $\mathrm{Mg}^{2+}$ levels, the lattice parameters, degree of crystallinity and unit cell volume of HA decreased significantly [46].

$\mathrm{Sr}$ and $\mathrm{Mg}$ co-substituted HA ( $\mathrm{Sr} / \mathrm{MgHA})$ showed an improved biocompatibility. An enhanced attachment, proliferation and differentiation of human osteoblast-like MG63 cells was observed in vitro [47]. Porous $\mathrm{Sr} / \mathrm{MgHA}$ has also been exploited to prolong the release of beneficial $\mathrm{Mg}$ during the bone regeneration process as well as to utilise the antiosteoporotic and anticarie properties of $\mathrm{Sr}$ ion [48].

$\mathrm{Na}$ and $\mathrm{Mg}$ have also been co-substituted into $\mathrm{HA}, \mathrm{Na} / \mathrm{MgHA}$ synthesized by a biomimetic precipitation method showed an enhanced bioactivity by promoting the growth of osteoblast cells in vitro [45]. 


\begin{tabular}{|c|c|c|c|c|c|}
\hline \multirow[t]{2}{*}{ Substitution } & \multirow[t]{2}{*}{ Empirical formula } & \multirow[t]{2}{*}{ Cytotoxicity } & \multirow{2}{*}{$\begin{array}{l}\text { In vitro (control: HA) } \\
\text { Cell }\end{array}$} & \multicolumn{2}{|l|}{ In vivo (control: HA) } \\
\hline & & & & Animal model & Tests \\
\hline MgHA $[21,22,23]$ & $\begin{array}{l}\mathrm{Ca}_{10-\mathrm{x}} \mathrm{Mg}_{\mathrm{x}}\left(\mathrm{PO}_{4}\right)_{6}(\mathrm{OH})_{2} \\
\mathrm{X}_{\mathrm{Mg}}=0.1\end{array}$ & N/A & $\begin{array}{l}\text { MC3T3-E1 P } \uparrow, \mathbf{D} \uparrow(A L P, \\
\text { OCN) }\end{array}$ & $\begin{array}{l}\text { Calvarial defects rabbits } \\
(8 \text { weeks })\end{array}$ & Bone growth $=$ \\
\hline SrHA $[24,25,26]$ & $\begin{array}{l}\mathrm{Ca}_{10-\mathrm{x}} \mathrm{Sr}_{\mathrm{x}}\left(\mathrm{PO}_{4}\right)_{6}(\mathrm{OH})_{2} \\
\mathrm{X}_{\mathrm{Sr}}=0.1,0.5,1\end{array}$ & N/A & $\begin{array}{l}\text { MG63 A } \uparrow, \mathbf{P} \uparrow \mathbf{D} \uparrow(\mathrm{ALP}, \mathrm{OCN}) \\
\mathrm{HOCC} \mathbf{P} \downarrow\end{array}$ & $\begin{array}{l}\text { Calvarial defect rats }(4 \\
\text { weeks) }\end{array}$ & $\begin{array}{l}\text { Bone growth } \uparrow, \text { density } \uparrow \text {, } \\
\text { Thickness } \uparrow\end{array}$ \\
\hline ZnHA [18] & $\begin{array}{l}\mathrm{Ca}_{10-\mathrm{x}} \mathrm{Zn}_{\mathrm{x}}\left(\mathrm{PO}_{4}\right)_{6}(\mathrm{OH})_{2} \\
\mathrm{X}_{\mathrm{Zn}}=0.105\end{array}$ & $>1.2 \mathrm{wt} \%$ & $\begin{array}{l}\text { MSCs } \mathbf{P} \uparrow, \mathbf{D} \uparrow(\mathrm{COL}, \mathrm{OCN}) \\
\mathrm{HOCC} \mathbf{P} \downarrow\end{array}$ & N/A & N/A \\
\hline CoHA [27] & $\begin{array}{l}\mathrm{Ca}_{10-\mathrm{x}} \mathrm{Co}_{\mathrm{x}}\left(\mathrm{PO}_{4}\right)_{6}(\mathrm{OH})_{2} \\
\mathrm{X}_{\mathrm{Co}}=0.22,0.40,0.54\end{array}$ & $>0.25 \mathrm{nM} / \mathrm{L}$ & $\begin{array}{l}\text { Caco-2 } \mathbf{P} \uparrow \\
\text { MC3T3-E1 } \mathbf{P} \downarrow\end{array}$ & Alveolar bone defect rat & $\begin{array}{l}\text { Bone growth }(6 \text { weeks }) \uparrow \\
\text { Blood vessel formation }(24 \text { weeks }) \uparrow\end{array}$ \\
\hline CuHA [28] & $\begin{array}{l}\mathrm{Ca}_{10-\mathrm{x}} \mathrm{Cu}_{\mathrm{x}}\left(\mathrm{PO}_{4}\right)_{6}(\mathrm{OH})_{2} \\
\mathrm{X}_{\mathrm{Cu}}=0.06\end{array}$ & $>0.80 \mathrm{wt} \%$ & MC3T3-E1A=, $\mathbf{P} \uparrow$ & N/A & N/A \\
\hline NaHA [20] & $\begin{array}{l}\mathrm{Ca}_{10-\mathrm{x}} \mathrm{Na}_{\mathrm{x}}\left(\mathrm{PO}_{4}\right)_{6}(\mathrm{OH})_{2} \\
\mathrm{X}_{\mathrm{Na}}=0.05\end{array}$ & N/A & MC3T3-E1P $\uparrow$ & $\begin{array}{l}\text { Calvarial defects rabbits } \\
\text { (4 weeks) }\end{array}$ & Bone growth $\uparrow$ \\
\hline AgHA [29] & $\mathrm{Ca}_{10-\mathrm{x}} \mathrm{Ag}_{\mathrm{x}}\left(\mathrm{PO}_{4}\right)_{6}(\mathrm{OH})_{2}$ & $>1.6 \mathrm{ppm}$ & N/A & N/A & N/A \\
\hline CeHA $[30,31]$ & $\begin{array}{l}\mathrm{Ca}_{10-\mathrm{x}} \mathrm{Ce}^{3+}{ }_{\mathrm{x}}\left(\mathrm{PO}_{4}\right)_{6}(\mathrm{OH})_{2} \\
\mathrm{X}_{\mathrm{Ce}}=0.07\end{array}$ & $>50 \mathrm{ug} / \mathrm{ml}$ & MG63 P $\downarrow$ & N/A & N/A \\
\hline GaHA [32] & $\mathrm{Ca}_{10-\mathrm{x}} \mathrm{Ga}_{\mathrm{x}}\left(\mathrm{PO}_{4}\right)_{6}(\mathrm{OH})_{2}$ & N/A & $\mathrm{HOCC} \mathbf{P} \downarrow$ & N/A & N/A \\
\hline EuHA $[33,34]$ & $\begin{array}{l}\mathrm{Ca}_{10-\mathrm{x}} \mathrm{Eu}_{\mathrm{x}}\left(\mathrm{PO}_{4}\right)_{6}(\mathrm{OH})_{2} \\
\mathrm{X}_{\mathrm{Eu}}=0.005,0.01\end{array}$ & + & MG63 P $\uparrow$ & N/A & N/A \\
\hline TiHA [35] & $\begin{array}{l}\mathrm{Ca}_{10-\mathrm{x}} \mathrm{Ti}_{\mathrm{x}}\left(\mathrm{PO}_{4}\right)_{6}(\mathrm{OH})_{2} \\
\mathrm{X}_{\mathrm{Ti}}=0.28\end{array}$ & N/A & $\mathrm{HOBC} \uparrow$ & N/A & N/A \\
\hline SiHA $[21,36]$ & $\begin{array}{l}\mathrm{Ca}_{10}\left(\mathrm{PO}_{4}\right)_{6-\mathrm{x}}\left(\mathrm{SiO}_{4}\right)_{\mathrm{x}}(\mathrm{OH})_{2} \\
\mathrm{X}_{\mathrm{Si}}=0.008,0.22,0.48\end{array}$ & N/A & $\mathrm{HOBC} \mathbf{A} \uparrow, \mathbf{P} \uparrow$ & N/A & N/A \\
\hline FHA [37, 38, 39] & $\begin{array}{l}\mathrm{Ca}_{10}\left(\mathrm{PO}_{4}\right)_{6}(\mathrm{OH})_{2-\mathrm{x}} \mathrm{F}_{\mathrm{x}} \\
\mathrm{X}_{\mathrm{F}}=0.16\end{array}$ & N/A & MG63 P $\uparrow$ & N/A & N/A \\
\hline $\mathrm{CHA}(\mathrm{A})[40,41]$ & $\mathrm{Ca}_{10}\left(\mathrm{PO}_{4}\right)_{6-\mathrm{x}}\left(\mathrm{CO}_{3}\right)_{\mathrm{x}}(\mathrm{OH})_{2}$ & N/A & \multirow{2}{*}{$\begin{array}{l}\text { MSCs \& MG-63 P } \uparrow \mathbf{D} \uparrow(\mathrm{COL}) \\
\text { human CD14+ } \mathbf{P} \uparrow\end{array}$} & \multirow[t]{2}{*}{ N/A } & \multirow[t]{2}{*}{ N/A } \\
\hline $\mathrm{CHA}(\mathrm{B})$ & $\mathrm{Ca}_{10}\left(\mathrm{PO}_{4}\right)_{6}(\mathrm{OH})_{2-\mathrm{x}}\left(\mathrm{CO}_{3}\right)_{\mathrm{x}}$ & N/A & & & \\
\hline
\end{tabular}

Table 2. A summary of in vitro and in vivo biological responses to mono-ionic substituted HA in comparison to HA.

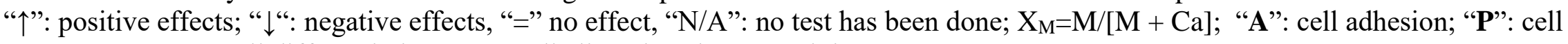
proliferation "D": Cell differentiation; ALP: Alkaline phosphatase activity, OCN: Osteocalcin secretion; COL: Type I collagen expression. 


\subsection{Substitution of Phosphate Group}

Phosphate group $\left(\mathrm{PO}_{4}{ }^{3-}\right)$ in $\mathrm{HA}$ has been substituted by chemical groups of $\mathrm{CO}_{3}{ }^{2-}, \mathrm{SiO}_{4}{ }^{4-}$, $\mathrm{SeO}_{3}{ }^{2-}$, to achieve variable biological purposes.

\section{Carbonate substituted HA (CHA)}

Carbonate naturally exists in bone mineral at a high level (7.4\%) (Table 1), so biological apatite is carbonate substituted HA. Carbonate, $\mathrm{CO}_{3}$, can substitute either for the hydroxyl $(\mathrm{OH})$ groups, or the phosphate groups, and the resulting apatite is designated as Type A or Type B, or Type A/B for both groups, respectively [57].

The replacement of the large tetrahedral phosphate ion by the small planar carbonate ion leads to changes in lattice parameters: decrease a-axis and increase c-axis. The substitution of $\mathrm{CO}_{3}{ }^{2-}$ into HA decreases the symmetry and stability of the apatite structure and results in an increase of the solubility [57].

Synthetic carbonate substituted HA $(\mathrm{CHA})\left(\mathrm{Ca}_{10}\left(\mathrm{PO}_{4}\right)_{6-\mathrm{x}}\left(\mathrm{CO}_{3}\right)_{\mathrm{x}}(\mathrm{OH})_{2-\mathrm{y}}\left(\mathrm{CO}_{3}\right)_{\mathrm{y}}\right)$ has a similar chemical composition to natural bone. CHAs are more soluble than carbonate-free synthetic apatites, which lead to an enhanced bone forming ability both in vitro [6] and in vivo [58]. The solubility or biodegradability of CHA increased with its carbonate content in the composition [21].

\section{Multi-ionic co-substituted CHA}

The co-substitution of metal ions such as $\mathrm{Na}^{+}$or $\mathrm{Mg}^{2+}$ with $\mathrm{CO}_{3}{ }^{2-}$ naturally exists in bone apatite (Table 3). The decrease of the crystallite size in $\mathrm{Na} / \mathrm{CHA}$ is correlated with the increasing of $\mathrm{Na}^{+}$and $\mathrm{CO}_{3}{ }^{2-}$ content, and the carbonate groups tend to accumulate in $\mathrm{B}$-sites instead on A-sites [59]. The carbonate concentration in $\mathrm{Na} / \mathrm{CHA}$ ranges from 1.3 to $6.0 \mathrm{wt} . \%$, while $\mathrm{Na}^{+}$could incorporate into CHA for up to $1.5 \mathrm{wt} \%$, similar to natural bone [59]. There is a positive correlation between carbonate and sodium content with the maturation of human 


\begin{tabular}{|c|c|c|c|c|}
\hline & Empirical formula & Tests & Time & Control \\
\hline $\mathrm{Mg} / \mathrm{CHA}[40]$ & $\begin{array}{l}\mathrm{Ca}_{10-\mathrm{x}} \mathrm{Mg}_{\mathrm{x}}\left(\mathrm{PO}_{4}\right)_{6}(\mathrm{OH})_{2-\mathrm{y}}\left(\mathrm{CO}_{3}\right)_{\mathrm{y}} \\
1 \text { wt. } \% \mathrm{Mg} ; 6 \text { wt. } \% \mathrm{CO}_{3}^{2-}\end{array}$ & $\begin{array}{l}\text { MG63: P: } \uparrow \mathbf{D}(\text { ALP) }: \downarrow \\
\text { MSCs: P: } \uparrow \mathbf{D}(\text { ALP) }: \downarrow\end{array}$ & $7 \mathrm{~d}$ & HA CHA \\
\hline \multirow[t]{2}{*}{ Sr/CHA $[49,50]$} & \multirow{2}{*}{$\begin{array}{l}\mathrm{Ca}_{10-\mathrm{x}} \mathrm{Sr}_{\mathrm{x}}\left(\mathrm{PO}_{4}\right)_{6}(\mathrm{OH})_{2-\mathrm{y}}\left(\mathrm{CO}_{3}\right)_{\mathrm{y}} \\
\mathrm{X}_{\mathrm{Sr}}=0.05 ; \mathrm{X}_{\mathrm{CO}_{3}^{2-}}=0.05\end{array}$} & MC3T3-E1 $\mathbf{P} \uparrow$ Cell membrane integrity $\uparrow$ & $24 \mathrm{~h}$ & 5 at.\% CHA \\
\hline & & New Zealand rabbits bone formation $\uparrow$ & 4,12 weeks & CHA \\
\hline \multirow[t]{2}{*}{$\mathrm{Mg} / \mathrm{AgHA}[51]$} & \multirow{2}{*}{$\begin{array}{l}\mathrm{Ca}_{10-\mathrm{x}-\mathrm{Mgg}} \mathrm{Mg}_{\mathrm{x}} \mathrm{Ag}_{\mathrm{y}}\left(\mathrm{PO}_{4}\right)_{6}(\mathrm{OH})_{2} \\
1 \mathrm{wt} \% \mathrm{Mg} ; 2.5 \mathrm{wt} \% \mathrm{Ag}\end{array}$} & MG63 $\mathbf{P} \uparrow$ & $24 \mathrm{~h}$ & \multirow[t]{2}{*}{$2.5 \mathrm{wt} \% \mathrm{AgHA}$} \\
\hline & & E. coli $\downarrow$ & $24 \mathrm{~h}$ & \\
\hline $\mathrm{Mg} / \mathrm{SrHA}[47]$ & $\begin{array}{l}\mathrm{Ca}_{10-\mathrm{x}-\mathrm{y}} \mathrm{Mg}_{\mathrm{x}} \mathrm{Sr}_{\mathrm{y}}\left(\mathrm{PO}_{4}\right)_{6}(\mathrm{OH})_{2} \\
\mathrm{X}_{\mathrm{Mg}}=0.1 ; \mathrm{X}_{\mathrm{Sr}}=0.2\end{array}$ & $\mathrm{MG}-63 \mathbf{A} \uparrow \mathbf{P} \uparrow \mathbf{D}(\mathrm{ALP}) \uparrow$ & $1,3,7 \mathrm{~d}$ & HA \\
\hline \multirow[t]{2}{*}{ F/MgHA [52] } & \multirow{2}{*}{$\begin{array}{l}\mathrm{Ca}_{10-\mathrm{x}} \mathrm{Mg}_{\mathrm{x}}\left(\mathrm{PO}_{4}\right)_{6}(\mathrm{OH})_{2-\mathrm{y}} \mathrm{F}_{\mathrm{y}} \\
\mathrm{X}_{\mathrm{Mg}}=0.11\end{array}$} & MG63 P $\uparrow$ & $1,3,5 \mathrm{~d}$ & \multirow[t]{2}{*}{ FHA } \\
\hline & & $\mathbf{D} \uparrow(\mathrm{ALP})$ & $7,14,21 \mathrm{~d}$ & \\
\hline F/SrHA [53] & $\begin{array}{l}\mathrm{Ca}_{10-\mathrm{x}} \mathrm{Sr}_{\mathrm{x}}\left(\mathrm{PO}_{4}\right)_{6}(\mathrm{OH})_{2-\mathrm{y}} \mathrm{F}_{\mathrm{y}} \\
1.48 \mathrm{wt} \% \mathrm{~F} ; 5.32 \mathrm{wt} \% \mathrm{Sr}\end{array}$ & MC3T3-E1 P $\uparrow$ & $7,11 \mathrm{~d}$ & HA \\
\hline \multirow[t]{2}{*}{ Sr/CeHA [54] } & \multirow{2}{*}{$\begin{array}{l}\mathrm{Ca}_{10-\mathrm{x}-\mathrm{yr}} \mathrm{Sr}_{\mathrm{x}} \mathrm{Ce}_{\mathrm{y}}\left(\mathrm{PO}_{4}\right)_{6}(\mathrm{OH})_{2} \\
\mathrm{X}_{\mathrm{Sr}}=0.25 ; \mathrm{X}_{\mathrm{Ce}}=0.125\end{array}$} & E. coli $\downarrow$, S. aureus $\downarrow$ & $24 \mathrm{~h}$ & \multirow{2}{*}{$\begin{array}{l}\text { HA } \\
\text { 25at.\% SrHA }\end{array}$} \\
\hline & & In vitro apatite forming ability in SBF $\uparrow$ & $7,14,21 \mathrm{~d}$ & \\
\hline \multirow[t]{3}{*}{$\mathrm{Sr} / \mathrm{CuHA}[55]$} & \multirow{3}{*}{$\begin{array}{l}\mathrm{Ca}_{10-\mathrm{x}-\mathrm{S}} \mathrm{Sr}_{\mathrm{x}} \mathrm{Cu}_{\mathrm{y}}\left(\mathrm{PO}_{4}\right)_{6}(\mathrm{OH})_{2} \\
\mathrm{Sr}: 6.74 \mathrm{wt} \% ; \mathrm{Cu}: 1.59 \mathrm{wt} \%\end{array}$} & MG63 P $\uparrow$ & $3,5 \mathrm{~d}$ & \multirow[t]{3}{*}{ Pure titanium } \\
\hline & & $\mathbf{D} \uparrow(\mathrm{ALP})$ & $7,14 d$ & \\
\hline & & E. coli $\downarrow$ & $24 \mathrm{~h}$ & \\
\hline \multirow[t]{2}{*}{$\mathrm{Cu} / \mathrm{ZnHA}[56]$} & \multirow{2}{*}{$\begin{array}{l}\mathrm{Ca}_{10-\mathrm{x}-\mathrm{y}} \mathrm{Cu}_{\mathrm{x}} \mathrm{Zn}_{\mathrm{y}}\left(\mathrm{PO}_{4}\right)_{6}(\mathrm{OH})_{2} \\
\mathrm{X}_{\mathrm{Cu}}=0.037 ; \mathrm{X}_{\mathrm{Zn}}=0.037\end{array}$} & MC3T3-E1 = & $24 \mathrm{~h}$ & \multirow[t]{2}{*}{ HA } \\
\hline & & E. coli $\downarrow$ & $4,7 \mathrm{~d}$ & \\
\hline
\end{tabular}

Table 3. A summary of in vitro and in vivo biological responses to multi-ionic co-substituted HA

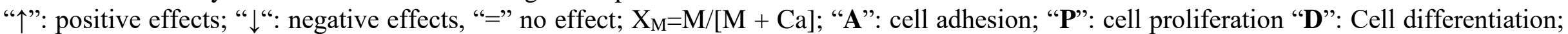
ALP: Alkaline phosphatase activity; SBF: Simulated body fluid 
bones, in comparison to a negative correlation for that of carbonate and magnesium [59].

The increase of $\mathrm{Mg}^{2+}$ and $\mathrm{CO}_{3}{ }^{2-}$ in $\mathrm{Mg} / \mathrm{CHA}$ also reduces the crystallinity and increases the dissolution of $\mathrm{Mg} / \mathrm{CHA}$. In vitro study showed that $\mathrm{Mg} / \mathrm{CHA}$ could enhance the cellular adhesion, proliferation and differentiation of mesenchymal stem cells (MSCs) and MG63 cells [60].

Recently, $\mathrm{Zn}^{2+}$ or $\mathrm{Sr}^{2+}$ has been co-substituted with carbonates to promote bone remodelling. Both $\mathrm{Zn}$ and carbonate inhibit the crystal growth in HA $[49,61]$. The incorporation of $\mathrm{Sr}^{2+}$ and $\mathrm{CO}_{3}{ }^{2-}$ in $\mathrm{HA}$ was aimed to combine the therapeutic function of $\mathrm{Sr}^{2+}$ and bioactivity of carbonate to improve the osteointegration and new bone formation rate, especially in the $\mathrm{Sr}$ deficiency pathologies. Moreover, Sr/CHA scaffold has been produced with interconnected micro- and macro-porosity to mimics the morphology of spongy bone. This specific porous structure can promote $\mathrm{Sr} / \mathrm{CHA}$ as a resorbable bone replacement in orthopaedic or dental applications $[49,61]$.

\section{Silicate substituted HA (SiHA)}

Silicon is an essential trace element for bone and cartilage formation, and plays a crucial role in bone mineralisation and skeletal development [62, 63]. Si has positive effects to the expression of VEGF, which could stimulate both blood vessel and bone formation (Table 2) [64].

The surface charge of silicate substituted HA (SiHA) was significantly more negative compared to pure HA, which led to a higher protein absorption, and promoting cell attachment, proliferation and differentiation for enhanced bone formation [65]. The silicate substitution in SiHA inhibited grain growth, which led to an increase of the total surface area/volume ratio of grain boundaries [67-68]. In vitro and in vivo bioactivity was enhanced with silicate substitutions into the HA lattice $[69,70,71]$. The enhanced bioactivity of SiHA is also related to increased solubility as well as reduced grain size and nano-topography [66]. There were many researches have compared the bioactivity of SiHA with varied Si content. It is commonly agreed that there is an optimal $\mathrm{Si}$ content for cell culture. In vitro experiment based on osteogenic differentiation (ALP and OC) and in vivo experiments based on the bone formation and bone ingrowth have all indicated that the $0.8 \mathrm{wt} \%$ Si has shown optimal responses $[72,73$, 74, 75]. SiHA as bone graft, commercially known as Actifuse ${ }^{\mathrm{TM}}$ (Apatech Ltd, UK), has been used successfully for spinal, orthopaedic, periodontal, oral and craniomaxillofacial applications. 


\section{Multi-ionic co-substituted SiHA}

There were many elements have been co-substituted with $\mathrm{Si}$ into $\mathrm{HA}$ to improve biocompatibility and bioactivity, such as $\mathrm{Mg}, \mathrm{Mn}, \mathrm{CO}_{3}, \mathrm{Na}, \mathrm{Sr}$ and $\mathrm{Ag}[75,76,77,78,79]$. The co-substitution of $\mathrm{Sr}$ and $\mathrm{Si}$ into HA could increase the levels of substitutions of both elements to further improve their degradability. Sr/SiHA has positive effect to cellular proliferation and differentiation of osteoblasts and MSCs cells, in comparison with mono- SiHA and SrHA [80]. The SBF test showed a fast formation of an apatite layer on the surface of $\mathrm{Na} / \mathrm{Si} / \mathrm{CHA}$ coating, indicating its potential for medical application [81].

\subsection{Substitution of Hydroxyl group}

In addition to type A CHA, other anions such $\mathrm{F}^{-}, \mathrm{Cl}^{-}$could also be substituted into $\mathrm{HA}$ by replacing hydroxyl groups. $\mathrm{Cl}^{-}$and $\mathrm{F}^{-}$naturally exist in human bone at the concentration of $0.13 \mathrm{wt} \%$ and $0.03 \mathrm{wt} \%$ respectively. Both mono- and co-substitutions were found to enhance the bioactivity.

\section{Fluoride substituted HA (FHA)}

The fluoride substitution leads to an increased crystallinity, crystal size and the stability of the apatite, thus reduces solubility. The presence of $\mathrm{F}$ in enamel crystals helps to resist dissolution in the acidic oral environment. Fluoride substituted HA (FHA) has been used in dental applications for a long time. FHA has a better osteointegration in bone tissue in comparison to HA in vivo [82]. It has good biocompatibility, low solubility, and good thermal and chemical stability [83]. Therefore, FHA is a good therapeutic candidate in the treatment of osteoporosis. Fluoride ions $\left(\mathrm{F}^{-}\right)$released from FHA was found to promote the in vitro osteoblastic activities by enhancing the cell adhesion, proliferation, differentiation and mineralization (Table 2) [83].

\section{Chloride substituted HA (CIHA)}

ClHA has attracted an attention due to the positive effects to bone resorption processes (Table 2) [3]. Chloride ions $\left(\mathrm{Cl}^{-}\right)$do not substitute readily for $\mathrm{OH}^{-}$into $\mathrm{HA}$ as a result of the larger ionic size. ClHA was found to develop an acidic environment on the surface of materials, which could activate osteoclasts in the bone resorption process. $\mathrm{Cl}^{-}$ions could increase the hydrolases 
secretion of osteoclasts and enhance the organic matrix digestion activity [84]. In addition, the osteoconductivity of ClHA was demonstrated in vitro (Table 2) [84].

\section{Multi-ionic co-substituted HA}

The co-substitution of anions offers another way to enhance the cytocompatibility of HA. Different combinations of anions including $\mathrm{F}^{-}, \mathrm{Cl}^{-}$and $\mathrm{CO}_{3}{ }^{2-}$ have been well studied.

An acidic environment created by $\mathrm{ClHA}$ can promote osteoclasts activity, enhance the solubilization rate of bone mineral and digest the organic matrix. The co-substitution of $\mathrm{F}^{-}$and $\mathrm{Cl}^{-}$could counteract the potential side effect of $\mathrm{Cl}^{-}$, e.g., the dementia in elderly patients, and the addition of $\mathrm{F}^{-}$ions could enhance the proliferation and differentiation of bone cells, in addition to inhibit the dental caries [85].

The co-substitution of $\mathrm{F}^{-}$and $\mathrm{CO}_{3}{ }^{2-}$ into $\mathrm{HA}$ structure has been made with $\mathrm{CO}_{3}{ }^{2-}$ substituted into $\left(\mathrm{PO}_{4}^{3-}\right)$ site and $\mathrm{F}^{-}$for $\mathrm{OH}^{-}$site [86], in order to improve the bone formation as well as inhibition the bone resorption. The co-existence of $\mathrm{F}^{-}$and $\mathrm{CO}_{3}{ }^{2-}$ increased the crystallinity, an enhanced bone regeneration (in comparison with HA and CHA) was observed [86]. A low and sustained release rate of $\mathrm{F}^{-}$could also be maintained to guarantee a safe therapeutic effect of $\mathrm{F}^{-}$ [87].

\section{Antibacterial substituted HA}

HA has been successfully used as bioactive coatings for implants. The bacterial contamination at implant insertion sites can cause implant failure [54]. Substitution of $\mathrm{Ca}^{2+}$ with antibacterial ions such as $\mathrm{Ag}^{+}, \mathrm{Ce}^{3+}, \mathrm{Zn}^{2+}, \mathrm{Cu}^{2+}$, into the $\mathrm{HA}$ structure is a way to provide the antibacterial ability while maintaining excellent biocompatibility (Table 4).

\section{Silver substituted HA (AgHA)}

Silver and its alloys have been used as antimicrobial materials for centuries. Ag-containing materials could inhibit a broad spectrum of bacteria, viruses and fungi (Table 4). Ag substituted HA (AgHA) has attracted more attention due to the improvement of physical and chemical properties of HA, such as crystallinity and solubility [88]. AgHA showed a good biocompatibility, strong antibacterial ability and high thermal stability, making it a potential coating material for implants [88]. The antibacterial mechanism of $\mathrm{Ag}^{+}$is dependent on the 
structural damages within the bacterial membrane as well as the negative effects on bacterial DNA and RNA, which could inhibit the reproduction of bacterium [88].

\section{Cerium substituted HA (CeHA)}

The physicochemical and biological properties of $\mathrm{Ce}$ is similar to calcium, and it also has antibacterial ability. Ce has been used for antibacterial applications for a long time [54]. The substitution of $\mathrm{Ce}^{3 / 4+}$ into HA (SeHA) could increase the solubility and further improve the biodegradability and antibacterial ability [54], and inhibition the growth of E. coli, S. aureus and Lactobacillus has been demonstrated (Table 4) [54].

\section{Zinc substituted HA (ZnHA)}

Besides its biocompatibility, ZnHA could inhibit the adhesion and surface growth of bacteria by generating reactive oxygen species (ROS), thus significantly decreases viabilities of bacteria [95]. In addition, the released zinc ions can form strong bonds with the membrane proteins of bacteria, and further trigger the structural changes to the membranes and contribute to killing effect. Particularly, the antibacterial ability of ZnHA can be achieved at a low concentration $(<1 \mathrm{wt} \%)$ and inhibited a broad spectrum of bacterial species including E. coli, S. aureus, C. albicans and S. mutans (Table 4) [95].

\section{Copper substituted HA (CuHA)}

Copper substituted HA (CuHA) in a low concentration $(0.8 \mathrm{wt} \%)$ has shown a strong antimicrobial effect while maintaining a low cytotoxicity. CuHA inhibits a list of microorganisms, including gram-positive ( $S$. aureus), gram-negative (E. coli) bacteria and yeast (C. albicans) (Table 4). The antibacterial mechanism of $\mathrm{Cu}^{2+}$ ions has been studied, $\mathrm{Cu}^{2+}$ ions are able to undermine bacterial outer cell membrane, which changes the cell permeability and release the cell contents [28].

\section{Titanium substituted HA (TiHA)}

Titanium substituted HA (TiHA) was able to inhibit the growth of both Gram-negative and Gram-positive bacterial strains (Table 4). Particularly, TiHA nanoparticles were able to inhibit the growth of multi-antibiotic resistant EMRSA 15 and EMRSA 16 'superbugs'[96]. Thus 


\begin{tabular}{|c|c|c|c|c|c|c|c|}
\hline \multirow[t]{2}{*}{ Substitution } & \multirow[t]{2}{*}{ Empirical formula } & \multicolumn{2}{|c|}{ Test condition } & \multicolumn{3}{|c|}{ Antimicroorganism ability } & \multirow{2}{*}{$\begin{array}{l}\text { Antimicrobial test } \\
\text { methods }\end{array}$} \\
\hline & & Conc. & Time & E. $\operatorname{coli}(\mathrm{G}-)$ & S. aureus $(\mathrm{G}+)$ & C. albicans (Fungi) & \\
\hline $\operatorname{AgHA}[29,89]$ & $\begin{array}{l}\mathrm{Ca}_{10-\mathrm{x}} \mathrm{Ag}_{\mathrm{x}}\left(\mathrm{PO}_{4}\right)_{6}(\mathrm{OH})_{2} \\
\mathrm{X}_{\mathrm{Ag}}=0.0002,0.0004,0.004\end{array}$ & $10 \mathrm{mg} / \mathrm{ml}$ & $2 \mathrm{~h}$ & +++ & +++ & +++ & $\begin{array}{l}\text { Log reduction } \\
\text { assay }\end{array}$ \\
\hline $\mathrm{CuHA}[56,90]$ & $\begin{array}{l}\mathrm{Ca}_{10-\mathrm{x}} \mathrm{Cu}_{\mathrm{x}}\left(\mathrm{PO}_{4}\right)_{6}(\mathrm{OH})_{2} \\
\mathrm{X}_{\mathrm{Cu}}=0.0004,0.004\end{array}$ & $10 \mathrm{mg} / \mathrm{ml}$ & $2 \mathrm{~h}$ & +++ & +++ & +++ & $\begin{array}{l}\text { Plate-counting } \\
\text { method }\end{array}$ \\
\hline $\mathrm{ZnHA}[18]$ & $\begin{array}{l}\mathrm{Ca}_{10-\mathrm{x}} \mathrm{Zn}_{\mathrm{x}}\left(\mathrm{PO}_{4}\right)_{6}(\mathrm{OH})_{2} \\
\mathrm{X}_{\mathrm{Zn}}=0.0004,0.004\end{array}$ & $10 \mathrm{mg} / \mathrm{ml}$ & $2 \mathrm{~h}$ & +++ & +++ & ++ & $\begin{array}{l}\text { Agar diffusion } \\
\text { method }\end{array}$ \\
\hline $\mathrm{CoHA}[91]$ & $\begin{array}{l}\mathrm{Ca}_{10-\mathrm{x}} \mathrm{Co}_{\mathrm{x}}\left(\mathrm{PO}_{4}\right)_{6}(\mathrm{OH})_{2} \\
\mathrm{X}_{\mathrm{Co}}=0.018,0.045,0.091\end{array}$ & $10 \mathrm{mg} / \mathrm{ml}$ & $24 \mathrm{~h}$ & N/A & +++ & N/A & $\begin{array}{l}\text { Media poisoning } \\
\text { method }\end{array}$ \\
\hline TiHA[35] & $\begin{array}{l}\mathrm{Ca}_{10-\mathrm{x}} \mathrm{Ti}_{\mathrm{x}}\left(\mathrm{PO}_{4}\right)_{6}(\mathrm{OH})_{2} \\
\mathrm{X}_{\mathrm{Ti}}=0.028,0.056,0.28\end{array}$ & $10 \mathrm{mg} / \mathrm{ml}$ & $24 \mathrm{~h}$ & ++ & N/A & N/A & $\begin{array}{l}\text { Viable count } \\
\text { (spread plate) } \\
\text { method }\end{array}$ \\
\hline CeHA[92] & $\begin{array}{l}\mathrm{Ca}_{10-\mathrm{x}} \mathrm{Ce}_{\mathrm{x}}\left(\mathrm{PO}_{4}\right)_{6}(\mathrm{OH})_{2} \\
\mathrm{X}_{\mathrm{Ce}}=0.08,0.12,0.16,0.20\end{array}$ & $100 \mathrm{mg} / \mathrm{ml}$ & $18 \mathrm{~h}$ & ++ & ++ & N/A & $\begin{array}{l}\text { Shake flask } \\
\text { method }\end{array}$ \\
\hline SrHA[93] & $\begin{array}{l}\mathrm{Ca}_{10-\mathrm{x}} \mathrm{Sr}_{\mathrm{x}}\left(\mathrm{PO}_{4}\right)_{6}(\mathrm{OH})_{2} \\
\mathrm{X}_{\mathrm{Sr}}=0.05,0.1\end{array}$ & $0.1 \mathrm{mg} / \mathrm{ml}$ & $24 \mathrm{~h}$ & + & + & N/A & $\begin{array}{l}\text { Colony count } \\
\text { quantitative } \\
\text { method }\end{array}$ \\
\hline EuHA[33] & $\begin{array}{l}\mathrm{Ca}_{10-\mathrm{x}} \mathrm{Eu}_{\mathrm{x}}\left(\mathrm{PO}_{4}\right)_{6}(\mathrm{OH})_{2} \\
\mathrm{X}_{\mathrm{Ce}}=0.05,0.1,0.2\end{array}$ & $1 \mathrm{mg} / \mathrm{ml}$ & $18 \mathrm{~h}$ & + & - & ++ & $\begin{array}{l}\text { VITEK II } \\
\text { automatic system }\end{array}$ \\
\hline SeHA[32, 94] & $\begin{array}{l}\mathrm{Ca}_{10}\left(\mathrm{PO}_{4}\right)_{6-\mathrm{x}}\left(\mathrm{SeO}_{3}\right)_{\mathrm{x}}(\mathrm{OH})_{2} \\
\mathrm{X}_{\mathrm{Se}}=0.006\end{array}$ & Solid test & $24 \mathrm{~h}$ & No biofilm $\mathrm{f}$ & ion & N/A & Plate-based assays \\
\hline
\end{tabular}

Table 4. A summary of antimicroorganism tests of substituted HA.

"+": inhibition; "-": no inhibition; "N/A": no test has been done.

"+++": inhibition rate $>95 \%$ "++": inhibition rate $=75-95 \%$ "+": inhibition rate $<75 \% ; \mathrm{X}_{M}=\mathrm{M} /[\mathrm{M}+\mathrm{Ca}]$, the inhibition rate of red $\mathrm{X}_{\mathrm{M}}$ were shown in the table. 
TiHA coatings have a potential to offer both antibacterial abilities and osteoconductivity for dental and orthopaedic implants [35].

\section{Multi-ionic co-substituted HA}

Co-substitution of cations or anions into the HA structure can offer multifunctional materials, such as providing the antibacterial ability in addition to promote biocompatibility. There are three groups of co-substitutions in HA, including cationic for cationic, anionic for anionic and both cationic-anionic substitutions.

Cations with antibacterial abilities were co-substituted into HA with biocompatible elements to achieve the anti-infection abilities whilst maintaining bioactivity. For example, antibacterial ions such as $\mathrm{Ce}^{3 / 4+}, \mathrm{Ag}^{+}, \mathrm{Cu}^{2+}$ and $\mathrm{Zn}^{2+}$ co-substituted into $\mathrm{HA}$ together with bioactive cations such as $\mathrm{Sr}^{2+}, \mathrm{Mg}^{2+}$ and $\mathrm{Si}^{4+}$ have been well studied [54, 55, 28, 79, 55, 75].

In vitro studies showed that the co-substitution of $\mathrm{Sr}$ and $\mathrm{Ce}(\mathrm{Sr} / \mathrm{CeHA})$ greatly improved the bioactivity and biocompatibility. In addition, antibacterial study against two prokaryotic strains (E. coli and S. aureus) indicated that Sr/CeHA has a strong antibacterial ability [54]. Cosubstitution of $\mathrm{Sr}^{2+}$ and $\mathrm{Cu}^{2+}$ into $\mathrm{HA}$ (Sr/CuHA) has been investigated for their cytocompatibility and antibacterial ability. An in vitro test showed the bactericidal effect of $\mathrm{Sr} / \mathrm{CuHA}$ against $E$. coli. The addition of $\mathrm{Sr}^{2+}$ not only can reduce the cytotoxicity of $\mathrm{Cu}^{2+}$, but also promote the osseointegration potential [55]. Similar results were also found in $\mathrm{Sr}^{2+}$ and $\mathrm{Cu}^{2+}$ co-substituted $\mathrm{HA}(\mathrm{Cu} / \mathrm{ZnHA})$, in which, $\mathrm{Zn}^{2+}$ ions counteracted the cytotoxicity of $\mathrm{Cu}^{2+}$. There was no cytotoxicity effects of $\mathrm{Cu} / \mathrm{ZnHA}$ to osteoblast-like MC3T3-E1 cells, while the antibacterial ability against E.coli was maintained [28].

Similarly, $\mathrm{Ag}^{+}$has also been co-substituted into HA with biocompatible elements, such as $\mathrm{Mg}^{2+}$, $\mathrm{Si}^{4+}$ to reduce the potential cytotoxicity of $\mathrm{Ag}^{+}$. In $\mathrm{Ag} / \mathrm{MgHA}$, the antibacterial ability is provided by $\mathrm{Ag}^{+}$ions, and the existence of $\mathrm{Mg}^{2+}$ could reduce the cytotoxicity of $\mathrm{Ag}^{+}$ions [51]. $\mathrm{Ag} / \mathrm{SiHA}$ was able to enhanced the differentiation of human adipose-derived mesenchymal stem cells on $\mathrm{Ag} / \mathrm{SiHA}$, in addition to 7-log reduction of $S$. aureus population [75]. Therefore, by complement of $\mathrm{Ag}$ and Si into HA structure, a synergy, combining of antibacterial property with enhanced bioactivities, can be achieved in Ag/SiHA for potential bone replacement.

\section{Substituted HA for Drug delivery}

One of the major limitations in the treatment of many diseases is the lack of bioactive drug delivery systems. Designing appropriate drug delivery systems is required to achieve site- 
specific, desirable distribution or selective delivery of therapeutic compounds. Moreover, drug delivery systems should also prevent the rapid degradation of drugs while maintaining the drug concentrations in targeted tissue sites [97].

The potential of HA based materials as delivery systems has been investigated [98]. There are three types of HA drug delivery systems, including drugs conjugated HA scaffolds, porous HA nanoparticles and polymer coated HA particles. The current applications have been mainly focused on treating bone related diseases, such as chronic osteomyelitis and bone cancer [98]. The bioactivity of HA has attracted more attention in drug delivery applications, as it can help for specific targeting and minimizing the side effect. Depending on the substitutions into HA, several biofunctions have been achieved, such as controlled delivery and release of drugs, in vitro and in vivo gene transfection, and magnetic hyperthermia therapy. A range of materials, from antibiotics, drugs, amino acids, genes, antigens, to magnetic ions or fluorescent molecules for imaging and monitoring of drug delivery [29].

HA has been developed as a theranostic system, which combined the controlled drug delivery (rate and amount) with the diagnostics response [99]. Diagnostic and therapeutic materials could be coated on or encapsulated together into HA structure to achieve the drug delivery function in response to the diagnostic results. For example, the dissolution of HA is higher in low $\mathrm{pH}$ environment, which normally occurs in the vicinity of tumours, thus providing a drug delivery carrier for cancer treatment [100].

\section{Monitoring of Drug Release}

Luminescent HA has been obtained by substitutions of lanthanide groups ions, such as $\mathrm{Eu}^{3+}$, and $\mathrm{Gd}^{3+}$ into HA. The addition of luminescence of HA could monitor drug release, tracking the drug distribution and monitoring the drug-releasing rate. SrHA nanorods have been used for the controlled release of ibuprofen (IBU) [101], and $\mathrm{Eu}^{3+}$ and $\mathrm{Gd}^{3+}$ co-substituted HA has been employed to monitor of the drug (IBU) release (in vitro) and distribution (in vivo) at the injected sites (buttock and back) of male nude mice [102]. Moreover, lanthanide ions substituted HA could maintain the biological functions of HA, such as bone remodelling and treatment of osteoporosis [97].

\section{Cancer treatment}


Magnetic HA has been developed by substituting $\mathrm{Fe}^{2+/ 3+}$ or $\mathrm{Co}^{2+}$ into HA structure, which could transport drugs to the affected sites and kill only tumor cells while exerting no harm to normal cells. Fe substituted HA (FeHA) is the most common magnetic substituted HA and has a potential in the cancer treatment as a heating mediator in hyperthermia therapy. The test of magnetically induced thermal property of FeHA nanoparticles showed the temperature increased rapidly from $25^{\circ} \mathrm{C}$ to $40{ }^{\circ} \mathrm{C}$ in 60s [103]. Injection of FeHA nanoparticles into the tumor sites in vivo (a mice model), a dramatic reduction (48.5\%) of the tumor size was observed after 3 days [104].

On the other hand, selenium (Se) is a nutritional trace element and is related to many biological functions such as immune, thyroid and reproductive functions. The phosphate site of HA can be replaced by Se and formed Se substituted HA (SeHA). SeHA nanoparticles possess anticancer ability both in vitro and in vivo [105]. For example, a prolonged lifespan of nude mice in vivo (with human hepatocellular carcinoma) was observed, even the tumour size was not decreased. This was because SeHA was able to maintain the kidney and liver functions that were undermined by cancer [105].

\section{Gene delivery}

Conventional gene delivery system is viral based, HA has been considered as an alternative to viral gene delivery system. By encapsulating DNA or RNA molecules into HA structures could protect them from cytoplasmatic environment and to be delivered into cell nucleus [100]. The advantages of HA as genetic transfection agents are related to the physical and chemical structure of HA. HA could permeate the cell walls and be ingested by the cells, which can maintain a high cellular uptake. Moreover, the resorbability of HA can be controlled to ensure a gradual and sustained release rate of DNA [100]. Although the gene transfection efficiency of HA is lower, but HA is well known to be safer. Particularly in comparison with polymeric based gene delivery carriers, such as Poly (lactic acid) (PLLA) that can be harmful to surrounding tissues due the acidic degradation products. In contrast, the degradation of HA does not release any toxic chemicals [100]. Core-shell HA particles with multi-layered structures have also been developed for multiple therapeutic components to be released at different time or sites [106].

Besides the DNA delivery approach, antisense strategy has been developed to produce a gene knockdown tools, which compositing gene silencing materials such as siRNA into HA and be delivered into cytoplasm for gene modification [107]. 
Calcium phosphate ceramics, and HA in particular, have attracted much attention in biomedical fields. Substituted HA has been developed for repair and regeneration of the diseased or damaged tissues. By substitution approaches, many biological functions can be specifically designed into HA based materials. The potential applications of substituted HA include bioactive coatings for implants to promote osteoconductivity and osteoinductivity; antibacterial potential for the long-term stability and success of related implants; high biocompatibility for drug or gene delivery. Moreover, a biomagnetic HA can pave the way in the hyperthermia therapy for cancer treatment.

However, there is still a lack of comprehensive understanding of the biological behaviour of these substituted HA in order for the laboratory research to be taken into clinical practice. For the further development of HA related materials, great efforts and collaborations are still required for researchers in many research fields, from biology, chemistry, materials science and engineering to biomedical and clinical fields.

\section{References:}

1. Posner AS. Crystal chemistry of bone mineral. . Physiological reviews. 1969;49(4):760-792.

2. Dorozhkin SV, \& Epple, M. . Biological and medical significance of calcium phosphates. Angewandte Chemie International Edition. 2002;41((17)):3130-3146.

3. Šupová M. Substituted hydroxyapatites for biomedical applications: A review. Ceramics International. 2015;41(8):9203-9231.

4. Long SRAMP. Role of Cellular Magnesium in Human Diseases. Austin J Nutr Food Sci. 2010;2(10): 1051.

5. Landi E, Logroscino G, Proietti L, et al. Biomimetic Mg-substituted hydroxyapatite: from synthesis to in vivo behaviour. J Mater Sci Mater Med. 2008 Jan;19(1):239-47.

6. Stipniece L, Stepanova V, Narkevica I, et al. Comparative study of surface properties of Mgsubstituted hydroxyapatite bioceramic microspheres. Journal of the European Ceramic Society. 2018;38(2):761-768.

7. Wu L, Luthringer BJ, Feyerabend $F$, et al. Effects of extracellular magnesium on the differentiation and function of human osteoclasts. Acta Biomater. 2014 Jun;10(6):2843-54.

8. Geesink RG, de Groot, K., \& Klein, C. P. Bonding of bone to apatite-coated implants. Bone \& Joint Journal. 1988;70(1):17-22.

9. Hanawa T, Kamiura, Y., Yamamoto, S., Kohgo, T., Amemiya, A., Ukai, H., ... \& Asaoka, K. . Early bone formation around calcium - ion - implanted titanium inserted into rat tibia. . Journal of Biomedical Materials Research: An Official Journal of The Society for Biomaterials and The Japanese Society for Biomaterials. 1997;36(1):131-136.

10. Birgani ZT, Gharraee N, Malhotra A, et al. Combinatorial incorporation of fluoride and cobalt ions into calcium phosphates to stimulate osteogenesis and angiogenesis. Biomed Mater. 2016 Feb 29;11(1):015020.

11. Xie H, Smith LJ, Holmes AL, et al. The cytotoxicity and genotoxicity of soluble and particulate cobalt in human lung epithelial cells. Environ Mol Mutagen. 2016 May;57(4):282-287.

12. Bose S, Fielding G, Tarafder S, et al. Understanding of dopant-induced osteogenesis and angiogenesis in calcium phosphate ceramics. Trends Biotechnol. 2013 Oct;31(10):594-605. 
13. Ignjatovic N, Ajdukovic Z, Rajkovic J, et al. Enhanced Osteogenesis of Nanosized Cobaltsubstituted Hydroxyapatite. Journal of Bionic Engineering. 2015;12(4):604-612.

14. Qiao Y, Zhang W, Tian P, et al. Stimulation of bone growth following zinc incorporation into biomaterials. Biomaterials. 2014 Aug;35(25):6882-6897.

15. Bigi A, Foresti, E., Gandolfi, M., Gazzano, M., \& Roveri, N. . Inhibiting effect of zinc on hydroxylapatite crystallization. Journal of Inorganic Biochemistry. 1995;58(1):49-58.

16. LeGeros RZ, \& LeGeros, J. P. Dense hydroxyapatite. In An introduction to bioceramics. 1993:139-180.

17. Ratnayake JTB, Mucalo M, Dias GJ. Substituted hydroxyapatites for bone regeneration: A review of current trends. J Biomed Mater Res B Appl Biomater. 2017 Jul;105(5):1285-1299.

18. Thian ES, Konishi T, Kawanobe $\mathrm{Y}$, et al. Zinc-substituted hydroxyapatite: a biomaterial with enhanced bioactivity and antibacterial properties. J Mater Sci Mater Med. 2013 Feb;24(2):437445.

19. Lin K, Liu P, Wei L, et al. Strontium substituted hydroxyapatite porous microspheres: Surfactantfree hydrothermal synthesis, enhanced biological response and sustained drug release. Chemical Engineering Journal. 2013;222:49-59.

20. Sang Cho J, Um SH, Su Yoo D, et al. Enhanced osteoconductivity of sodium-substituted hydroxyapatite by system instability. J Biomed Mater Res B Appl Biomater. 2014 Jul;102(5):1046-1062.

21. Shepherd JH, Shepherd DV, Best SM. Substituted hydroxyapatites for bone repair. J Mater Sci Mater Med. 2012 Oct;23(10):2335-2347.

22. Ma J, Chen CZ, Wang DG, et al. Effect of magnesia on the degradability and bioactivity of solgel derived $\mathrm{SiO}_{2}-\mathrm{CaO}-\mathrm{MgO}-\mathrm{P}_{2} \mathrm{O}_{5}$ system glasses. Colloids Surf B Biointerfaces. $2010 \mathrm{Nov}$ 1;81(1):87-95.

23. Zhao SF, Jiang QH, Peel S, et al. Effects of magnesium-substituted nanohydroxyapatite coating on implant osseointegration. Clin Oral Implants Res. 2013 Aug;24 Suppl A100:34-41.

24. Song $W$, Wang $Q$, Wan $C$, et al. A novel alkali metals/strontium co-substituted calcium polyphosphate scaffolds in bone tissue engineering. J Biomed Mater Res B Appl Biomater. 2011 Aug;98(2):255-262.

25. Capuccini C, Torricelli P, Sima F, et al. Strontium-substituted hydroxyapatite coatings synthesized by pulsed-laser deposition: in vitro osteoblast and osteoclast response. Acta Biomater. 2008 Nov;4(6):1885-1893.

26. Lin K, Xia L, Li H, et al. Enhanced osteoporotic bone regeneration by strontium-substituted calcium silicate bioactive ceramics. Biomaterials. 2013 Dec;34(38):10028-10042.

27. Ignjatovic N, Ajdukovic Z, Savic V, et al. Nanoparticles of cobalt-substituted hydroxyapatite in regeneration of mandibular osteoporotic bones. J Mater Sci Mater Med. 2013 Feb;24(2):343354.

28. Huang $\mathrm{Y}$, Zhang $\mathrm{X}$, Zhao $\mathrm{R}$, et al. Antibacterial efficacy, corrosion resistance, and cytotoxicity studies of copper-substituted carbonated hydroxyapatite coating on titanium substrate. Journal of Materials Science. 2014;50(4):1688-1700.

29. Lim PN, Teo EY, Ho B, et al. Effect of silver content on the antibacterial and bioactive properties of silver-substituted hydroxyapatite. J Biomed Mater Res A. 2013 Sep;101(9):2456-2464.

30. Kaygili O, Dorozhkin SV, Keser S. Synthesis and characterization of Ce-substituted hydroxyapatite by sol-gel method. Mater Sci Eng C Mater Biol Appl. 2014 Sep;42:78-82.

31. Ciobanu C, Popa C, Predoi D. Cerium doped hydroxyapatite nanoparticles synthesized by coprecipitation method. Journal of the Serbian Chemical Society. 2016;81(4):433-446.

32. Kolmas J, Groszyk E, Kwiatkowska-Rozycka D. Substituted hydroxyapatites with antibacterial properties. Biomed Res Int. 2014;2014:178123.

33. Iconaru S-L, Motelica-Heino M, Predoi D. Study on Europium-Doped Hydroxyapatite Nanoparticles by Fourier Transform Infrared Spectroscopy and Their Antimicrobial Properties. Journal of Spectroscopy. 2013;2013:1-10.

34. Gopi D, Sathishkumar S, Karthika A, et al. Development of Ce3+/Eu3+ Dual-Substituted Hydroxyapatite Coating on Surgical Grade Stainless Steel for Improved Antimicrobial and Bioactive Properties. Industrial \& Engineering Chemistry Research. 2014;53(52):20145-20153.

35. Li Y, Ho J, Ooi CP. Antibacterial efficacy and cytotoxicity studies of copper (II) and titanium (IV) substituted hydroxyapatite nanoparticles. Materials Science and Engineering: C. 2010;30(8):1137-1144.

36. Thian ES, Huang J, Best SM, et al. The response of osteoblasts to nanocrystalline siliconsubstituted hydroxyapatite thin films. Biomaterials. 2006 May;27(13):2692-2698.

37. Bianco A, Cacciotti I, Lombardi M, et al. F-substituted hydroxyapatite nanopowders: Thermal 
stability, sintering behaviour and mechanical properties. Ceramics International. 2010;36(1):313-322.

38. Kannan S, Rocha JH, Agathopoulos S, et al. Fluorine-substituted hydroxyapatite scaffolds hydrothermally grown from aragonitic cuttlefish bones. Acta Biomater. 2007 Mar;3(2):243-249.

39. Kim HW, Noh, Y. J., Koh, Y. H., \& Kim, H. E. Enhanced performance of fluorine substituted hydroxyapatite composites for hard tissue engineering. Journal of Materials Science: Materials in Medicine. 2003;14(10):899-904.

40. Landi E, Tampieri A, Mattioli-Belmonte $\mathrm{M}$, et al. Biomimetic Mg- and $\mathrm{Mg}, \mathrm{CO}_{3}$-substituted hydroxyapatites: synthesis characterization and in vitro behaviour. Journal of the European Ceramic Society. 2006;26(13):2593-2601.

41. Spence G, Patel N, Brooks R, et al. Carbonate substituted hydroxyapatite: resorption by osteoclasts modifies the osteoblastic response. J Biomed Mater Res A. 2009 Jul;90(1):217224.

42. Arifin A, Sulong AB, Muhamad N, et al. Material processing of hydroxyapatite and titanium alloy ( $\mathrm{HA} / \mathrm{Ti})$ composite as implant materials using powder metallurgy: A review. Materials \& Design. 2014;55:165-175.

43. Huang J, Best SM, Bonfield W, et al. Development and characterization of titanium-containing hydroxyapatite for medical applications. Acta Biomater. 2010 Jan;6(1):241-249.

44. Kim H-W, Koh Y-H, Li L-H, et al. Hydroxyapatite coating on titanium substrate with titania buffer layer processed by sol-gel method. Biomaterials. 2004;25(13):2533-2538.

45. Yoruc $A B H$, Aydinoglu $A$. The precursors effects on biomimetic hydroxyapatite ceramic powders. Mater Sci Eng C Mater Biol Appl. 2017 Jun 1;75:934-946.

46. Kaygili O, Keser S. Sol-gel synthesis and characterization of $\mathrm{Sr} / \mathrm{Mg}, \mathrm{Mg} / \mathrm{Zn}$ and $\mathrm{Sr} / \mathrm{Zn}$ co-doped hydroxyapatites. Materials Letters. 2015;141:161-164.

47. Geng Z, Wang R, Li Z, et al. Synthesis, characterization and biological evaluation of strontium/magnesium-co-substituted hydroxyapatite. J Biomater Appl. 2016 Jul;31(1):140-151.

48. Landi E, Uggeri J, Medri V, et al. Sr, Mg cosubstituted HA porous macro-granules: potentialities as resorbable bone filler with antiosteoporotic functions. J Biomed Mater Res A. 2013 Sep;101(9):2481-2490.

49. Landi E, Sprio S, Sandri M, et al. Development of $\mathrm{Sr}$ and $\mathrm{CO}_{3}$ co-substituted hydroxyapatites for biomedical applications. Acta Biomater. 2008 May;4(3):656-663.

50. Valiense $\mathrm{H}$, Barreto $\mathrm{M}$, Resende RF, et al. In vitro and in vivo evaluation of strontium-containing nanostructured carbonated hydroxyapatite/sodium alginate for sinus lift in rabbits. J Biomed Mater Res B Appl Biomater. 2016 Feb;104(2):274-282.

51. Gopi D, Shinyjoy E, Kavitha L. Synthesis and spectral characterization of silver/magnesium cosubstituted hydroxyapatite for biomedical applications. Spectrochim Acta A Mol Biomol Spectrosc. 2014 Jun 5;127:286-291.

52. Cai YL, Zhang, J. J., Zhang, S., Venkatraman, S. S., Zeng, X. T., Du, H. J., \& Mondal, D. Osteoblastic cell response on fluoridated hydroxyapatite coatings: the effect of magnesium incorporation. Biomedical Materials. 2010;5(5):054114.

53. Huang $\mathrm{Y}$, Ding $\mathrm{Q}$, Pang $\mathrm{X}$, et al. Corrosion behavior and biocompatibility of strontium and fluorine co-doped electrodeposited hydroxyapatite coatings. Applied Surface Science. 2013;282:456-462.

54. Gopi D, Ramya S, Rajeswari D, et al. Strontium, cerium co-substituted hydroxyapatite nanoparticles: Synthesis, characterization, antibacterial activity towards prokaryotic strains and in vitro studies. Colloids and Surfaces A: Physicochemical and Engineering Aspects. 2014;451:172-180.

55. Huang Y, Hao M, Nian X, et al. Strontium and copper co-substituted hydroxyapatite-based coatings with improved antibacterial activity and cytocompatibility fabricated by electrodeposition. Ceramics International. 2016;42(10):11876-11888.

56. Huang $\mathrm{Y}$, Zhang $\mathrm{X}$, Mao $\mathrm{H}$, et al. Osteoblastic cell responses and antibacterial efficacy of $\mathrm{Cu} / \mathrm{Zn}$ co-substituted hydroxyapatite coatings on pure titanium using electrodeposition method. RSC Advances. 2015;5(22):17076-17086.

57. Madupalli H, Pavan B, Tecklenburg MMJ. Carbonate substitution in the mineral component of bone: Discriminating the structural changes, simultaneously imposed by carbonate in $A$ and $B$ sites of apatite. J Solid State Chem. 2017 Nov;255:27-35.

58. Xiao W, Sonny Bal B, Rahaman MN. Preparation of resorbable carbonate-substituted hollow hydroxyapatite microspheres and their evaluation in osseous defects in vivo. Mater Sci Eng C Mater Biol Appl. 2016 Mar;60:324-332.

59. Zyman Z, Tkachenko M. Sodium-carbonate co-substituted hydroxyapatite ceramics. 
Processing and Application of Ceramics. 2013;7(4):153-157.

60. Douglas TEL, Lapa A, Samal SK, et al. Enzymatic, urease-mediated mineralization of gellan gum hydrogel with calcium carbonate, magnesium-enriched calcium carbonate and magnesium carbonate for bone regeneration applications. J Tissue Eng Regen Med. 2017 Dec;11(12):3556-3566.

61. Kumar GS, Thamizhavel A, Yokogawa Y, et al. Synthesis, characterization and in vitro studies of zinc and carbonate co-substituted nano-hydroxyapatite for biomedical applications. Materials Chemistry and Physics. 2012;134(2-3):1127-1135.

62. Carlisle EM. Silicon: a possible factor in bone calcification. Science. 1970;167(3916):279-280.

63. Carlisle EM. Silicon: an essential element for the chick. Science. 1972;178(4061):619-621.

64. $\mathrm{Li} \mathrm{H}$, Chang J. Bioactive silicate materials stimulate angiogenesis in fibroblast and endothelial cell co-culture system through paracrine effect. Acta Biomater. 2013 Jun;9(6):6981-6991.

65. Botelho CM, Lopes, M. A., Gibson, I. R., Best, S. M., \& Santos, J. D. . Structural analysis of Sisubstituted hydroxyapatite: zeta potential and X-ray photoelectron spectroscopy. Journal of Materials Science: Materials in Medicine. 2002;13(12):1123-1127.

66. Henstock JR, Canham LT, Anderson SI. Silicon: the evolution of its use in biomaterials. Acta Biomater. 2015 Jan;11:17-26.

67. Porter AE, Patel, N., Skepper, J. N., Best, S. M., \& Bonfield, W. Comparison of in vivo dissolution processes in hydroxyapatite and silicon-substituted hydroxyapatite bioceramics. Biomaterials. 2003;24(25):4609-4620.

68. Porter AE, Botelho CM, Lopes MA, et al. Ultrastructural comparison of dissolution and apatite precipitation on hydroxyapatite and silicon-substituted hydroxyapatite in vitro and in vivo. J Biomed Mater Res A. 2004 Jun 15;69(4):670-679.

69. Gibson IR, Best, S. M., \& Bonfield, W. Chemical characterization of silicon - substituted hydroxyapatite. Journal of Biomedical Materials Research Part A. 1999;44(1):422-428.

70. Patel N, Best, S. M., Bonfield, W., Gibson, I. R., Hing, K. A., Damien, E., \& Revell, P. A. A comparative study on the in vivo behavior of hydroxyapatite and silicon substituted hydroxyapatite granules. Journal of Materials Science: Materials in Medicine. 2002;13(12):1199-1206.

71. Patel N, Brooks, R. A., Clarke, M. T., Lee, P. M. T., Rushton, N., Gibson, I. R., \& Bonfield, W. In vivo assessment of hydroxyapatite and silicate-substituted hydroxyapatite granules using an ovine defect model. Journal of materials science: materials in medicine. 2005;16(5):429-440.

72. Balas F, Pérez - Pariente, J., \& Vallet - Regí, M. In vitro bioactivity of silicon - substituted hydroxyapatites. Journal of Biomedical Materials Research Part A,. 2003;66(2):364-375.

73. Patel N, Brooks, R. A., Clarke, M. T., Lee, P. M. T., Rushton, N., Gibson, I. R., ... \& Bonfield, W. In vivo assessment of hydroxyapatite and silicate-substituted hydroxyapatite granules using an ovine defect model. Journal of materials science: materials in medicine. 2005;15(85):429-440.

74. Hing KA, Revell PA, Smith N, et al. Effect of silicon level on rate, quality and progression of bone healing within silicate-substituted porous hydroxyapatite scaffolds. Biomaterials. 2006 Oct;27(29):5014-5026.

75. Lim PN, Shi ZL, Neoh KG, Ho B, Tay BY,Thian ES, The effects of silver, silicon-containing apatite towards bacteria and cell responses, Biomedical Materials, 2014; 9 (1), 015010.

76. Kim SR, Lee, J. H., Kim, Y. T., Riu, D. H., Jung, S. J., Lee, Y. J., \& Kim, Y. H. Synthesis of Si, Mg substituted hydroxyapatites and their sintering behaviors. Biomaterials. 2003;24(8):13891398.

77. Büyükaksoy A, Köseoglu NC, Aslan MH, et al. Microstructural Study of Mn and Si Cosubstituted Hydroxyapatite Thin Films Produced by a Sol-Gel Method. Advanced Engineering Materials. 2009;11(7):B77-B81.

78. Mostafa NY, Hassan HM, Abd Elkader OH. Preparation and Characterization of $\mathrm{Na}+, \mathrm{SiO}_{4}^{4-}$, and $\mathrm{CO}_{3}{ }^{2-}$ Co-Substituted Hydroxyapatite. Journal of the American Ceramic Society. 2011;94(5):1584-1590.

79. Lim PN, Tay BY, Chan CM, et al. Synthesis and characterization of silver/silicon-cosubstituted nanohydroxyapatite. J Biomed Mater Res B Appl Biomater. 2012 Jan;100(1):285-291.

80. Zhang N, Zhai D, Chen L, et al. Hydrothermal synthesis and characterization of Si and Sr cosubstituted hydroxyapatite nanowires using strontium containing calcium silicate as precursors. Mater Sci Eng C Mater Biol Appl. 2014 Apr 1;37:286-291.

81. Leilei Z, Hejun L, Kezhi L, et al. A Na and Si co-substituted carbonated hydroxyapatite coating for carbon nanotubes coated carbon/carbon composites. Ceramics International. 2014;40(8):13123-13130.

82. Tsutsui S, Anada T, Shiwaku $\mathrm{Y}$, et al. Surface reactivity of octacalcium phosphate-derived 
fluoride-containing apatite in the presence of polyols and fluoride. J Biomed Mater Res B Appl Biomater. 2017 Oct 27: 2235-2244.

83. Suzuki $\mathrm{Y}$, Hayashi M, Tanabe N, et al. Effect of a novel fluorapatite-forming calcium phosphate cement with calcium silicate on osteoblasts in comparison with mineral trioxide aggregate. $\mathrm{J}$ Oral Sci. 2015 Mar;57(1):25-30.

84. Cho JS, Kim HS, Um SH, et al. Preparation of a novel anorganic bovine bone xenograft with enhanced bioactivity and osteoconductivity. J Biomed Mater Res B Appl Biomater. 2013 Jul;101(5):855-869.

85. Fahami A, Beall GW, Betancourt T. Synthesis, bioactivity and zeta potential investigations of chlorine and fluorine substituted hydroxyapatite. Mater Sci Eng C Mater Biol Appl. 2016 Feb;59:78-85.

86. Zhu Q-X, Li Y-M, Han D. Co-substitution of carbonate and fluoride in hydroxyapatite: Effect on substitution type and content. Frontiers of Materials Science. 2015;9(2):192-198.

87. Sogo $\mathrm{Y}$, Ito $\mathrm{A}$, Yokoyama $\mathrm{D}$, et al. Synthesis of fluoride-releasing carbonate apatites for bone substitutes. J Mater Sci Mater Med. 2007 Jun;18(6):1001-1007.

88. Franci G, Falanga A, Galdiero S, et al. Silver nanoparticles as potential antibacterial agents. Molecules. 2015 May 18;20(5):8856-8874.

89. Stanić V, Janaćković D, Dimitrijević S, et al. Synthesis of antimicrobial monophase silver-doped hydroxyapatite nanopowders for bone tissue engineering. Applied Surface Science. 2011;257(9):4510-4518.

90. Stanić V, Dimitrijević S, Antić-Stanković J, et al. Synthesis, characterization and antimicrobial activity of copper and zinc-doped hydroxyapatite nanopowders. Applied Surface Science. 2010;256(20):6083-6089.

91. Tank KP, Chudasama KS, Thaker VS, et al. Cobalt-doped nanohydroxyapatite: synthesis, characterization, antimicrobial and hemolytic studies. Journal of Nanoparticle Research. 2013;15(5): 1644.

92. Lin Y, Yang Z, Cheng J. Preparation, Characterization and Antibacterial Property of Cerium Substituted Hydroxyapatite Nanoparticles. Journal of Rare Earths. 2007;25(4):452-456.

93. Ravi ND, Balu R, Sampath Kumar TS, et al. Strontium-Substituted Calcium Deficient Hydroxyapatite Nanoparticles: Synthesis, Characterization, and Antibacterial Properties. Journal of the American Ceramic Society. 2012;95(9):2700-2708.

94. Rodriguez-Valencia C, Lopez-Alvarez M, Cochon-Cores B, et al. Novel selenium-doped hydroxyapatite coatings for biomedical applications. J Biomed Mater Res A. 2013 Mar;101(3):853-861.

95. Yang Y-C, Chen C-C, Wang J-B, et al. Flame sprayed zinc doped hydroxyapatite coating with antibacterial and biocompatible properties. Ceramics International. 2017;43:S829-S835.

96. Huang J, Li X, Koller GP, et al. Electrohydrodynamic deposition of nanotitanium doped hydroxyapatite coating for medical and dental applications. J Mater Sci Mater Med. 2011 Mar;22(3):491-496.

97. Mondal S, Dorozhkin SV, Pal U. Recent progress on fabrication and drug delivery applications of nanostructured hydroxyapatite. Wiley Interdiscip Rev Nanomed Nanobiotechnol. 2018, 10(4): e1504

98. Choi H, Jeena MT, Palanikumar L, et al. The HA-incorporated nanostructure of a peptide-drug amphiphile for targeted anticancer drug delivery. Chem Commun (Camb). 2016 Apr 25;52(32):5637-5640.

99. Blanco E, Kessinger CW, Sumer BD, et al. Multifunctional micellar nanomedicine for cancer therapy. Exp Biol Med (Maywood). 2009 Feb;234(2):123-131.

100. Uskokovic V, Uskokovic DP. Nanosized hydroxyapatite and other calcium phosphates: chemistry of formation and application as drug and gene delivery agents. J Biomed Mater Res B Appl Biomater. 2011 Jan;96(1):152-191.

101. Zhang C, Li C, Huang S, et al. Self-activated luminescent and mesoporous strontium hydroxyapatite nanorods for drug delivery. Biomaterials. 2010 Apr;31(12):3374-3383.

102. Chen F, Huang P, Zhu YJ, et al. The photoluminescence, drug delivery and imaging properties of multifunctional Eu3+/Gd3+ dual-doped hydroxyapatite nanorods. Biomaterials. 2011 Dec;32(34):9031-9039.

103. Tampieri A, D'Alessandro T, Sandri M, et al. Intrinsic magnetism and hyperthermia in bioactive Fe-doped hydroxyapatite. Acta Biomater. 2012 Feb;8(2):843-851.

104. Hou CH, Hou SM, Hsueh YS, et al. The in vivo performance of biomagnetic hydroxyapatite nanoparticles in cancer hyperthermia therapy. Biomaterials. 2009 Aug;30(23-24):3956-3960.

105. Yanhua W, Hao H, Li Y, et al. Selenium-substituted hydroxyapatite nanoparticles and their in 
vivo antitumor effect on hepatocellular carcinoma. Colloids Surf B Biointerfaces. 2016 Apr 1;140:297-306.

106. Sokolova V, Prymak O, Meyer-Zaika W, et al. Synthesis and characterization of DNAfunctionalized calcium phosphate nanoparticles. Materialwissenschaft und Werkstofftechnik. 2006;37(6):441-445.

107. Zhang M, Ishii A, Nishiyama N, et al. PEGylated Calcium Phosphate Nanocomposites as Smart Environment-Sensitive Carriers for siRNA Delivery. Advanced Materials. 2009;21(34):35203525. 
